\title{
APPLICATION OF THE AGRICULTURAL AND FOOD PRODUCTS TRADEMARK SERVING TO INCREASE THE AGRICULTURAL SECTOR COMPETITIVENESS
}

\author{
Marina Jovićević Simin ${ }^{1}$, Slobodan Živkucin ${ }^{2}$ \\ *Corresponding author E-mail: marsimin06@gmail.com
}

A R T I C L E I N F O
Original Article
Received: 22 March 2021
Accepted: 23 August 2021
doi:10.5937/ekoPolj2103645J
UDC 339.137.2:338.431]:631.5
7+641.1(088.72)

Keywords:

agricultural and food sector, export, trademark, goods classes, international competitiveness

JEL: Q17, Q18, 030, 034

\begin{abstract}
A B S T R A C T
The subject of this paper is a research of state, processes, and conditions for the use of agricultural and food product trademark, both in Serbia and worldwide. During the period between 2015 and 2019, the agricultural food products were among the most represented classes of goods in terms of trademark applications, according to the Nice Classification of goods and services, both in our country and worldwide. The aim of this paper is to promote the competitiveness of the agricultural sector, with an emphasis on non-price competition forms such as the trademark application and protection, with a particular focus on international application and protection via the Madrid Agreement These forms of non-price competition could become the main promoters of the Serbian economy and the expression of the country's identity, given that the image of product quality indirectly projects to the country's reputation as well.
\end{abstract}

(C) 2021 EA. All rights reserved.

\section{Introduction}

Nowadays, the economies must compete based on measurable indicators, such as national and foreign investments, export, tourism, etc. Globalisation has changed the game rules. An economy cannot flourish without investments, which partially depend on self - promotion, therefore all the countries should create their own positive identity. In such a situation, a program aiming to promote the development and protection of national trademarks could serve as an instrument of change.

Trademarks and the legal terms related thereto are the perfect instruments of economic development, providing a strong impact on equal participation in international trade.

1 Marina Jovićević Simin, Ph.D.,College of Professional Studies in Management and Business Communication, Modene 5, 21000 Novi Sad, Serbia, Phone: +381 021882892 , E-mail: marsimin06@gmail.com, ORCID ID (https://orcid.org/0000-0002-9317-9630)

2 Slobodan Živkucin, Ph.D.,College of Professional Studies in Management and Business Communication, Modene 5, 21000 Novi Sad, Serbia, Phone: +381 021882 892, E-mail: slobodanzivkucin@gmail.com, ORCID ID (https://orcid.org/0000-0001-6642-1041/) 
Such an instrument could be equally used in developing and developed countries, multinational corporations, and in small and medium enterprises.

Trademarks, as an integral part of intellectual property, serve as a means of transferring the goods and services, which is manifested through an increase in the trade volume of all the goods and services, both on national and international markets.

The existence of trademarks in a certain area provides the reputation and recognisability that shall enable a company from a developing country to attract investors or license buyers. This fact gains ground considering that the protected trademarks in developing countries represent more than $10 \%$ of total industrial sector companies' value, around $40 \%$ in the financial sector and sector of other services, and between $70 \%$ and $90 \%$ of production in the agricultural, food and luxury products sector (Olins, 2003). The policy of trademark protection and application perceived in this way, and supported by an export-oriented production, might secure a faster economic development. This indicates how important trademarks are today in the area of international trade, finances, and culture.

From the moment when the famous trademarks had become an important part of marketing strategy in the business world, the importance of trademark legal protection started to grow. A trademark that is clearly recognisable by the consumers, may be the most important single asset of the intellectual property, or even more valuable than all the types of assets owned by a company. For example, the "Coca Cola $\AA$ ", Nestle $\AA$, and "Marlboro $\AA$ " trademarks have proven to be the outstanding economic goods in terms of returns on the initial and current investments in their creation and protection (Merges at al., 2009)

Trademark protects a sign which serves to distinguish the goods, i.e. services on the market, and which can be graphically represented. This sign can contain the following: words, letters, slogans, numbers, images, drawings, colour arrangements, three-dimensional shapes, combinations of such signs, as well as musical phrases. A trademark is basically a name of a certain manufacturer's product in a certain product group. A trademark includes tangible qualities, such as appearance, performances, packaging, guarantees, and other accompanying documents. More importantly, a trademark includes the attributes projected by the consumer itself, beyond these tangible properties (Gilbert, 1999). These aspects may include the attitudes towards a company that manufactures the product or towards a trademark itself, beliefs regarding the relationship between one's own personality and a trademark, the relationship between the others and a trademark, etc.

Consequently, a trademark does not only constitute an exclusive, total, monopoly right, it also represents a certain value. A sign protected with a trademark represents the company's assets and it may be a subject of trade. A trademark that enjoys certain respect may attract and secure the clients, thus bringing excess profits. A trademark extends the patent's economic life. Regarding the aforementioned, a trademark's economic value is sometimes extremely high. In certain cases, it amounts to $50 \%$ of the company's total value or even $90 \%$ of its value (Manigodić, 2001). One of the economic definitions of 
trademark defines it as a distinguishing sign used by its holder to attract clients and which has become an increasingly frequent contemporary investment.

According to Kami Idris (Idris,2003), the aim of protection provided to commercial signs is to develop a market through diversification, that is, a possibility to distinguish the goods and services labelled with a trademark, based on their origin, quality, and reputation, i.e. the consumers' loyalty.

Trademarks, as part of the industrial property, had been recognised as a financial asset during the $1990 \mathrm{~s}$. At the beginning of the $21^{\text {st }}$ century, the most important task facing the companies shall be to understand the potential of their own trademarks (Bobrovszky, 2002). In the future, companies shall compete more and more on the contemporary markets based on their intangible values, and the real competition shall be the one among their reputations.

The goods, i.e. services must be marked and classified according to the classes from the Nice Agreement on the international classification of goods and services for the purpose of trademark registration. If the application fulfils the requirements for recognition of rights, the Intellectual Property Office passes a decision on trademark recognition and enters the recognised right, with necessary data, to the Trademark Register. A trademark certificate is issued to a trademark holder and a recognised right is being published in the Intellectual Property Gazette, issued by the Office bimonthly (Simin Jovićević, 2011).

In order to overcome a complicated and expensive procedure of protecting a company's sign in the international environment, as early as 1891, the Madrid Agreement Concerning the International Trademark Registration had been concluded. The Madrid Agreement made it possible for all the applicants coming from the member states of the Madrid Union to achieve the protection on territories of all or some member states, by submitting a single application to its national office. The Kingdom of Serbs, Croats, and Slovenes had been a „member of the Agreement from February 26, 1921, (Official Gazette of the SFRY” - International Agreements, no.2/74), (Besarović \& Žarković, 1999).

International registration is valid for 20 years, and its renewal is possible for an unlimited number of times (Simin Jovićević, 2012). The internationally registered trademark, during the first five years, depends on the validity of national registration in the country of origin.

\section{Materials and methods}

A scientific rationale of this paper lies in the fact that a topic of trademark application and protection in the area of agriculture and the food industry, serving to increase national economic competitiveness, has been insufficiently or too little explored in our economic theory. This research provides an utterly objective overview, given that the entire analytics is based on the specific data obtained from the public registers of the Intellectual Property Office of the Republic of Serbia and the World Intellectual Property Organisation (WIPO). 
The subject of this paper is a research of state, processes, and conditions for the use of agricultural and food product trademark, both in Serbia and worldwide, considering that agriculture is positioned at the top, that is, among the three leading industrial activities in class representation, in terms of trademark applications, in the world. The existence of products with a recognisable trademark is a prerequisite for an equal and successful international competition and global positioning of our agricultural and food products. The aim of this paper is to promote the competitiveness of the agricultural sector, with an emphasis on non-price competition forms such as the trademark application and protection, with a particular focus on international protection via the Madrid Agreement.

Regarding the general scientific methods used in this paper, we have applied the statistical methods for quantitative data processing. Using a statistical analysis, we have explained the structure, dynamics, interdependence, and the influence of trademark application and protection on competitiveness development through an increased export volume of agricultural products, both in our country and abroad. Speaking of the specific scientific methods, we have used the analysis and synthesis method, for comparing the development of national competitiveness regarding the trademark protection and by the geographical coordinates (Serbia and the member countries of Madrid Agreement on International Trademark Protection) in the period between 2015 and 2019. The most prominent types of analysis in this paper are as follows: Structural, functional, genetic, and comparative analysis.

Trademark application and protection in Serbia is an area of law that has been largely harmonised with the European Union's regulations and Agreement on Trade-Related Aspects of Intellectual Property Rights (TRIPS). Thanks to the fact that laws from this area have been of a relatively recent date, today we can talk about the continuation of the harmonisation process. The problem of the economy lies in the low level of application and protection of national, and especially international trademarks, and, by extension, the lack of business entities' willingness to apply the laws governing this area.

\section{Research background}

\section{Agriculture as a factor of economic development and wealth creation}

Agriculture is one of the world's largest industries globally, about 1 billion people work in the agricultural sector, which represents about $28 \%$ of the whole population employed in 2018. Share of the agricultural population in total and in certain countries, globally speaking, is as follows: China $25 \%$, India $41 \%$, Russia $5,6 \%$, USA $1,4 \%$, Turkey $18 \%$, Greece $11,6 \%$, Italy $4 \%$, Great Britain $1 \%$, France $2 \%$, Austria 3\%, Bulgaria $6 \%$, Poland $9 \%$, B\&H 15\%, Montenegro $8 \%$, Croatia $6 \%$ and in Serbia $15 \%$ (data.worldbank.org/indicator/sl.agr.empl.zs,2020). This is an important indicator of economic structure, leading us to a conclusion that the development of the agroindustrial sector is one of the main development directions. None of the countries in the world had found their way out of crises until resolving the problems in the agricultural sector (Simin Jovićević at al., 2016). 
In the period between 2015 and 2019, trademarks of agricultural and food products were positioned at the top, that is, among the three leading industrial activities in representation by classes for the trademark applications worldwide, and in 2016 and 2017 the share rose to $18 \%$. This fact encourages us in our endeavours to assume a leadership position in the production, processing, and marketing of agricultural and food products both on a domestic and international market.

Serbia possesses significant production, natural, and man-made resources as well as an export potential in agricultural production and processing, in the conditions of the national market's constrained capacity. A share of agriculture in Serbian GDP in the last couple of years has been within an interval of $9 \%$ and $11 \%$. However, if we analyse the total contribution of agriculture in the other economic sectors, such as the food industry, producers and processors of inputs and raw material, this share exceeds $30 \%$ of total GDP (Stanković, 2020).

The basic question is to what extent the national agriculture is capable to compete on the international market in terms of its organisation, concept, and orientation. The most important efficiency indicator of agro-industrial production and its influence on the change of competitiveness is - a country's current account balance. Our country has an export potential in agricultural production and processing, which is not valorised. The causes of such a situation lie in the absence of export development strategy and the appropriate incentive measures of economic policy (Simin Jovićević, 2020). The export-import balance of agricultural and food products is the best example thereof.

The most important agricultural products in the export for 2019 are as follows: mercantile corn in the amount of 502 million USD, frozen raspberry in the amount of 234 million USD, tobacco cigarettes in the amount of 196 million USD, fresh apples in the amount of 119 million USD, the other food products in the amount of 104 million, tobacco for smoking in the amount of 101 million USD, the animal feed in the amount of 88 million USD and the raw sunflower oil in the amount of 86 million USD.

Serbia's foreign trade balance regarding its agricultural and food industry in 2019 shows the export value of 3,6224 million USD, which constitutes an increase of 9.1\%, compared to the results achieved in 2018 (the amount was 3,319.5 million USD), with the participation in total commodity export of 18.5\% (Stanković, 2020). 
Table 1. Regional foreign trade structure of the agricultural and food sector of the Republic of Serbia, in the period between 2015 and 2019 (in million USD)

\begin{tabular}{|l|l|l|l|l|l|l|l|l|l|}
\hline & \multicolumn{9}{|l|}{ EU } \\
\hline & CEport & Import & Balance & Export & Import & Balance & Export & Import & Balance \\
\hline 2015 & 1367 & 948 & 419 & 920 & 173 & 747 & 270 & 46 & 224 \\
\hline 2016 & 1541 & 941 & 600 & 1252 & 140 & 1112 & 321 & 48 & 273 \\
\hline 2017 & 1622 & 864 & 758 & 890 & 146 & 744 & 318 & 37 & 281 \\
\hline 2018 & 1716 & 1297 & 419 & 941 & 162 & 779 & 370 & 41 & 329 \\
\hline 2019 & 1847 & 1339 & 508 & 1014 & 167 & 847 & 398 & 42 & 356 \\
\hline
\end{tabular}

Source: Stankovic, V, Statistical Office of the Republic of Serbia, Foreign trade statistics, ST 12, Announcement no. 25, year LXX, January 30, 2020.

According to data from Table 1. which refer to the period between 2015 and 2019, the export average in the EU was 49.2\%, and in the CEFTA Agreement countries 33.2\%, while in the Russian Federation was 9.7\%. The export average for the rest of the countries was $7.9 \%$. In the export of agricultural products in the EU, the primary products i.e. raw materials have been predominant (90\%). In the CEFTA Agreement countries, the export structure differs from the EU export, because it is about the products of higher finalisation level. The main export products are grain and grain products. What is noticeable in the structure of foreign trade with the Russian Federation is an everincreasing share of higher processing stage food products (Stanković, 2020).

The predominant export items are fruits, vegetables, and derivatives, grain, and sugar, while on the import side, besides the group of the so-called inelastic products (coffee, spices, citrus fruit, and protein animal feed) the significant amounts of meat, milk, fruits and vegetables, cattle feed and other derivatives are being represented.

Given the aforementioned, the Government policy should focus much more on the export, conditions of its realisation, method of planning thereof, in order to create an export strategy. The current practice of relying on the potential market surplus of goods for export must be stopped, and the export itself should be planned according to the demand on the global market. A potential in natural resources and comparative advantages of domestic agriculture, as well as the circumstances in the international environment, oblige us and even compel us to choose such an approach.

\section{Results and Discussions}

\section{Analysis of the submitted trademark applications in the period between 2015 and 2019 in Serbia}

In order to evaluate the condition of technological achievement and degree of economic growth in a country, and its position compared to other countries, a number of domestic trademark applications and registrations is relevant. 
In 2019, in the Republic of Serbia, 6799 trademark applications were submitted in total: 2093 domestic and 4706 international applications. Domestic applicants have submitted 1310, while the foreign ones 783 national trademark applications. The rise in the protection of both foreign and domestic trademarks indicates the rising rate of business activities by the companies in Serbia. Trade-in goods and services, supported by the protected trademarks, is the best way for our country to participate in international trade.

Table 2. Structure of the applied trademarks between 2015 and 2019

\begin{tabular}{|c|c|c|c|c|}
\hline \multicolumn{4}{|c|}{ Structure of Applications Filed from 2015 to 2019 } & \multirow{2}{*}{ Total } \\
\cline { 3 - 4 } Year & \multirow{2}{*}{$\begin{array}{c}\text { International } \\
\text { Applications }\end{array}$} & \multicolumn{2}{|c|}{ National Applications } & \\
\cline { 3 - 4 } & 4617 & 812 & 1341 & 6770 \\
\hline $\mathbf{2 0 1 5}$ & 3780 & 782 & 1437 & 5999 \\
\hline $\mathbf{2 0 1 6}$ & 4785 & 773 & 1309 & 6867 \\
\hline $\mathbf{2 0 1 7}$ & 4835 & 782 & 1408 & 7025 \\
\hline $\mathbf{2 0 1 8}$ & 4706 & 783 & 1310 & 6799 \\
\hline $\mathbf{2 0 1 9}$ & & &
\end{tabular}

Source: Gazette of Intellectual Property, Annual Report, 2020, Belgrade, p.32

The number of foreign applications submitted in a country is a measure of its attractiveness for the technology transfer and sales of new products on its market.

During 2019, 7701 trademarks were registered, out of which 5692 were based on the applications submitted via the Madrid system and 2009 based on the national trademark applications.

These indicators suggest that foreign applicants use more frequently the advantages of the Madrid system. Table 2 shows the growth trend of both domestic and international trademark applications in the last five years, which shows the rising importance of application and use of a trademark as a strategic instrument for conquering or maintaining a market segment, which has a direct impact on the business success of companies and affirmation of national economy.

Classes of goods and services related to the agricultural sector, pursuant to the Nice Classification of goods and services, belong to the classes marked with numbers 29, 30, 31, 32 and 33, 43 and encompass the following:

Class 29. Meat, fish, poultry, and game; meat derivatives; preserved, dried, and boiled fruit and vegetables; eggs, milk, and dairy products; edible oils and fats; dietary products based on proteins and carbohydrates as a diet, etc.

Class 30. Sugar, rice, coffee, tea, flour, cereals and grain products, bread, cakes, sweets, ice creams, molasses, yeast, vinegar, sauces, etc.

Class 31. The agricultural, garden forest products; fresh fruits and vegetables; seed, unprocessed grain, potato; cattle feed, etc.

Class 32. Beer, mineral water, and other non-alcoholic beverages; fruit beverages and fruit juices; syrups and other preparations for beverage production.

Class 33. Alcoholic beverages (besides beer), special vines, spirits, and liqueurs.

Class 43. Services of fruit and beverage safety, temporary storage. 
Table 3. Representation of classes related to the agricultural sector, pursuant to the Nice Classification of goods and services in the applications submitted between 2015 and 2019 in Serbia

\begin{tabular}{|l|l|l|l|l|l|l|l|l|l|l|l|l|l|l|}
\hline & $\begin{array}{l}\text { Klas } \\
\mathbf{2 9}\end{array}$ & $\mathbf{\%}$ & $\begin{array}{l}\text { Klas } \\
\mathbf{3 0}\end{array}$ & $\mathbf{\%}$ & $\begin{array}{l}\text { Klas } \\
\mathbf{3 1}\end{array}$ & $\mathbf{\%}$ & $\begin{array}{l}\text { Klas } \\
\mathbf{3 2}\end{array}$ & $\mathbf{\%}$ & $\begin{array}{l}\text { Klas } \\
\mathbf{3 3}\end{array}$ & $\mathbf{\%}$ & $\begin{array}{l}\text { Klas } \\
\mathbf{4 3}\end{array}$ & $\mathbf{\%}$ & $\begin{array}{l}\text { Total } \\
\text { Klass }\end{array}$ & $\mathbf{\%}$ \\
\hline $\mathbf{2 0 1 5}$ & 214 & 10,5 & 383 & 18,8 & 99 & 4,7 & 191 & 8,5 & 111 & 5,5 & 151 & 5,3 & 1.149 & $\mathbf{5 3 , 3}$ \\
\hline $\mathbf{2 0 1 6}$ & 223 & 10 & 414 & 18,6 & 94 & 4,2 & 175 & 7,8 & 114 & 5,1 & 122 & 5,4 & 1.142 & $\mathbf{5 1 , 1}$ \\
\hline $\mathbf{2 0 1 7}$ & 197 & 9,4 & 282 & 13,5 & 67 & 3,2 & 163 & 7,8 & 112 & 5,3 & 115 & 5,5 & 936 & $\mathbf{4 4 , 7}$ \\
\hline $\mathbf{2 0 1 8}$ & 281 & 12,8 & 365 & 16,6 & 103 & 4,7 & 176 & 8,0 & 130 & 5,9 & 137 & 6,2 & 1.192 & $\mathbf{5 4 , 2}$ \\
\hline $\mathbf{2 0 1 9}$ & 414 & 19,7 & 282 & 13,4 & 70 & 3,3 & 178 & 8,5 & 108 & 5,1 & 117 & 5,6 & 1.169 & $\mathbf{5 5 , 6}$ \\
\hline
\end{tabular}

Source: Author's calculation based on data from public registers of the Intellectual Property Office of the Republic of Serbia

Table 3 includes both domestic and foreign trademark applicants who submitted applications directly to the Intellectual Property Office in the period between 2015 and 2019, as already illustrated in Table 2. Table 4 encompasses only domestic trademarks in the mentioned 5-year period.

Table 4. Representation of national applied trademarks from the agricultural and food sector between 2015 and 2019 in Serbia

\begin{tabular}{|l|l|l|l|}
\hline & $\begin{array}{c}\text { National applications } \\
\text { submitted to the Intellectual } \\
\text { Property Office of Serbia }\end{array}$ & $\begin{array}{c}\text { \% share of domestic } \\
\text { agricultural and food } \\
\text { trademarks }\end{array}$ & $\begin{array}{c}\text { Applied trademarks of } \\
\text { agriculture and food } \\
\text { product }\end{array}$ \\
\hline $\mathbf{2 0 1 5}$ & 2.153 & $53,3 \%$ & 1.149 \\
\hline $\mathbf{2 0 1 6}$ & 2.219 & $51,1 \%$ & 1.142 \\
\hline $\mathbf{2 0 1 7}$ & 2.082 & $44,7 \%$ & 936 \\
\hline $\mathbf{2 0 1 8}$ & 2.240 & $54,4 \%$ & 1.192 \\
\hline $\mathbf{2 0 1 9}$ & 2.093 & $56,1 \%$ & 1.169 \\
\hline Total & $\mathbf{1 0 . 7 8 7}$ & $\mathbf{5 1 . 9 \%}$ & $\mathbf{5 . 5 9 8}$ \\
\hline
\end{tabular}

Source: Author's calculation

By analysing the applied trademarks in Serbia, according to classes of goods and services, especially in the area of agricultural and food products (classes 29, 30, 31, 32, 33, and 43), a conclusion can be drawn that participation in these trademarks prevails in the total number of applied trademarks. Out of a total number of national trademarks applications submitted to the Serbian Intellectual Property Office in all 45 classes, which amounts to 10.787 trademarks, in the period between 2015 and 2019, only six classes mentioned in the previous table belong to the agricultural and food sector, which is on average (51,9\%), i.e. 5.598 applied trademarks.

\section{Analysis of international trademark applications according to the Madrid Agreement with emphasis on protection in the sector of agriculture and food between 2015 and 2019}

According to the ranking of the ten most competitive areas by a number of applied and registered trademarks in the world, a trend can be followed concerning the supply of goods and services on the market. If we take into account that during the market 
research stage, most of the companies that understand the importance of trademarks and service marks first protect the name of their product and service, and only then enter the market, it is clear that a number of applied trademarks in certain classes can be an indicator of demand for goods and services on the market.

The Nice Classification is an international classification of goods and services for the purposes of trademark application and registration. It was established in 1957 by the Nice Agreement, administered by the World Intellectual Property Organization (WIPO), and is currently used by some 150 national and regional IP offices around the world. The Classification consists of a list of classes, together with explanatory notes and an alphabetical list of goods and services. There are 34 classes of goods and 11 classes of services in total. When filing a Madrid application, applicants must indicate all the goods and services for which registration is sought and the classes into which they fall, as it is not possible to add other goods and services and classes at a later date (World Intellectual Property Indicators, 2020).

For the purpose of statistical reporting, the 45 Nice classes can be grouped into 10 industry sectors. The scientific research, information, and communication technology sector which includes top Nice classes 9 and 42, among others, continue to account for the highest share $(20.6 \%)$ of all classes specified in the Madrid application field in 2019. It is followed by health and agricultural products and services, accounting for $11 \%$, etc., as the Figure 1 below shows.

Figure 1. International applications of trademarks by industry sector via the Madrid System in 2019.

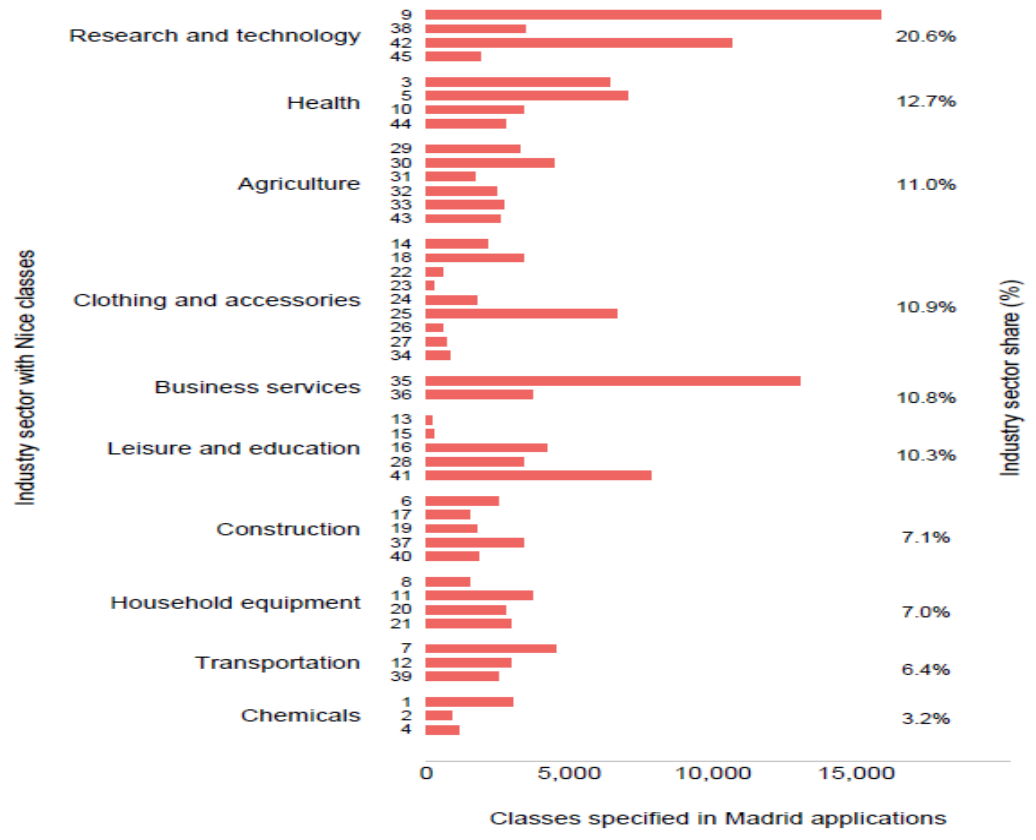

Source: Madrid Yearly Review, 2020, p.53 
The analysis of 10 leading classes by a number of applications and registrations in the period between 2015 and 2019, as well as their percentage compared to all 45 classes of goods and services pursuant to the international Nice Classification, according to which the international trademark applications are being classified, shows that the three most competitive sectors nowadays are research and development (information and communication technologies), followed by the health sector and finally the agricultural sector, i.e. agricultural and food products and services.

Figure 2.: International applications for the top 20 origins, 2019

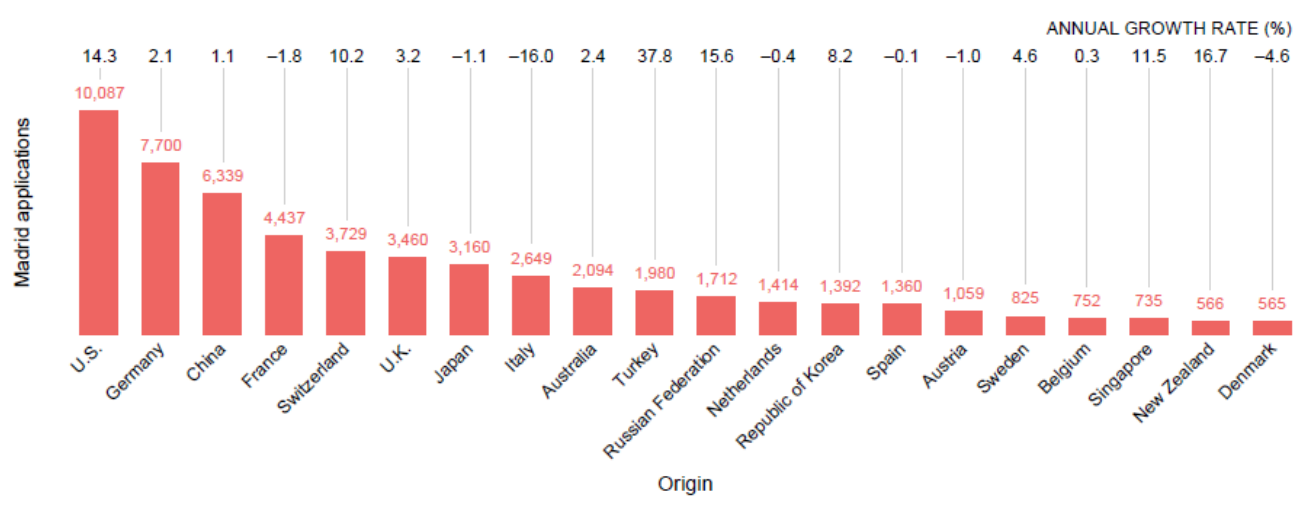

Source: Madrid Yearly Review, 2020, p.41

With annual growth of $14.3 \%$, applicants based in the U.S. consolidated their top ranking in 2019 by filing almost 2,400 more Madrid applications than the next topranked origin, Germany.

Table 5. Trademark applications by industry sector between 2015 and 2019

\begin{tabular}{|l|l|l|l|l|l|l|}
\hline \multicolumn{1}{|c|}{ Year } & \multicolumn{1}{|c|}{2015} & 2016 & 2017 & 2018 & 2019 & Total \\
\hline $\begin{array}{l}\text { International application } \\
\text { of trademarks via Madrid } \\
\text { System }\end{array}$ & 48.910 & 52.559 & 56.200 & 61.200 & 66.400 & 285.269 \\
\hline $\begin{array}{l}\text { International trademarks } \\
\text { application via Madrid } \\
\text { System in \% }\end{array}$ & $11,8 \%$ & $17,9 \%$ & $18 \%$ & $11,3 \%$ & $11 \%$ & $14 \%$ \\
\hline $\begin{array}{l}\text { International trademarks } \\
\text { application in the } \\
\text { Agriculture sector via } \\
\text { Madrid System }\end{array}$ & 5.820 & 9.408 & 10.116 & 6.916 & 7.304 & 39.564 \\
\hline
\end{tabular}

Source: Author's calculation

The analysis of applied trademarks in the area of agriculture and food industry in the world, according to the classes of goods and services (according to the Nice Classification of goods and services, those classes are (29, 30, 31, 32, 33 and 43), leads to a conclusion that the share of these trademarks is significant in a total number of applied and valid trademarks (Table 5). Out of a total number of applied trademarks, 
based on the Madrid Agreement in all the 45 classes, which amounts to 285,269 trademarks in the period between 2015 and 2019, the six mentioned classes only from the area of agriculture and food industry include 39,564 applied trademarks.

Therefore, out of a total number of international applied trademarks worldwide, in the period between 2015 and 2019, for all the 45 classes of goods and services, the largest share of trademarks related to the agriculture and food area was in $2016(17.9 \%)$ and $2017(18 \%)$, while the average share of these trademarks over the mentioned 5-year period amounts to $(14 \%)$.

In 2019, the World Intellectual Property Organization (WIPO) recorded 64,118 Madrid registrations, twice the amount issued by the early 2000s. The long-term trends for Madrid registrations broadly follow that for Madrid applications. Of the 1.5 million international registration recorded since the creation of the Madrid System, about half $(741,619)$ remained active - that is, in force - in 2019 (Madrid Yearly Review, 2020)-

A conclusion could be drawn that the trademarks in the area of agriculture and food industry are of primary importance, considering that compared to all the other industrial and other activities they participate with one-seventh (14\%) of all the international applied and registered trademarks in the period between 2015 and 2019.

\section{Conclusions}

In order to evaluate the condition of technological creation and economic growth in a country and its position compared to the other countries, a relevant input is a number of domestic trademark applications and registrations. Serbia is an agrarian country, and the importance of trademarks in the area of agricultural and food industry is of high priority, given that these trademarks, in the period between 2015 and 2019, were one of the most represented classes of goods and services in terms of trademark applications, both here and abroad. If we take into account that in 2015, 2016, and 2017, the agricultural and food products were positioned at the top, that is, were the most represented among the classes of goods regarding the trademark applications, here and abroad, it encourages us in our endeavour that companies in Serbia should assume a leadership position in marketing these products both on the national and international market.

Based on the conducted analysis of applied and protected trademarks in Serbia, according to classes of goods and services, especially in the area of agriculture and food products (classes 29,30,31,32,33, and 43), we may conclude that the share of these trademarks prevails in a total number of applied trademarks. Out of a total number of applied domestic trademarks in Serbia, considering all 45 classes, in the period between 2015 and 2019, as many as six classes belong to the agricultural and food industry sector, which on average amounts to $(51,9 \%)$.

In the period between 2015 and 2019, trademarks of the agricultural and food products were among the three leading industrial activities by class representation in terms of trademark applications, and in 2016 and 2017 share of these trademarks rose to $18 \%$. 
This fact encourages us in our endeavour to assume a leadership position in production, processing, and marketing agricultural and food products both on the national and international market.

Everything mentioned in this paper leads us to the conclusion that the importance of trademarks in the area of agriculture and food industry in the world is of high priority because compared to the industrial and other activities it participates in the range from $11 \%$ to $18 \%$, i.e. on average with one-seventh (14\%) of all the internationally applied and protected trademarks, in the period between 2015 and 2019.

Fact that a strategic orientation of our country is to become a full member of the European Union in the shortest possible time, should be used maximally by activating all the available domestic potentials. One of the most important preconditions in this process is to propose an agrarian program, which would secure a more favourable positioning of our agriculture and the entire economy in negotiations with the European Union.

The agricultural sector export restructuring with the emphasis on non-price forms of competition, such as the use and protection of trademark, especially the international protection via the Madrid Agreement should our most important national interest. These forms of non-price competition could become the main promoters of the Serbian economy and an expression of the country's identity, given that the image about a product quality indirectly projects to a country's reputation as well, as the Country-oforigin effect.

\section{Conflict of interests}

The authors declare no conflict of interest.

\section{References}

1. Besarović V., (2005), Intellectual Property, Industrial Property and Copyright, Publications Center Faculty of Law, Belgrade [In Serbian: Бесаровић B., (2005), Интелектуална својина, индустријска својина и ауторско право]

2. Besarović V., Žarković B., (1999), Intellectual property - international agreements, Dosije,Belgrade, p. 252, 474 [In Serbian: Бесаровић В., Жарковић Б., (1999), Интелектуална својина - међународни уговори]

3. Bobrovszky, J., (2002), Intellectual property as a means for quality development, World Intellectual Property Organization (WIPO), Geneve

4. Employment in agriculture ( $\%$ of total employment) - model ILO estimateded, Retrieved from: shttps://data.worldbank.org/indicator/sl.agr.empl. $\underline{\mathrm{zS}, 2020}, 25.02 .2021$

5. Gilbert, B., (1999), Retail Marketing Management, Financial Times, Prentice Hall, Harlow, England. 
6. Gazette of Intellectual Property, (2020), Annual Report, Office for Intellectual Property , Belgrade [In Serbian: Гласник интелектуалне својине, (2020), Годишњи извештај, Завод за интелектуалну својину]

7. Idris, K., (2003) ,Intellectual Property - The Power Mean Of Economic Growth, World Intellectual Property Organization (WIPO), Geneva.

8. Madrid Yearly Rewiew (2020), International Registration of Marks, World

9. Intellectual Property Organization (WIPO), Geneve

10. Manigodić M., (2001): Trademarks and service marks, Belgrade, [In Serbian: Манигодић М., (2001): Робни и услужни жигови]

11. Marković S., (2000): Intellectual property law, Official Gazette, Belgrade, .[In Serbian: Марковић С., (2000): Право интелектуалне својине]

12. Merges P.R., Menell S.P., Lemley A.M.,(2009) Intellectual Property in the New Technological Age, Aspen Publisher, Wolters Kluwer, Law\&Business.

13. Nice Classification of goods and services, Retrieved from: https://www.wipo.int/ classifications/nice (18.01.2021)

14. Olins W. (2003): On brand, Thames \& Hudson Ltd., London.

15. Stankovic, V.,Statistical Office of the Republic of Serbia, Foreign trade statistics, ST 12, Announcement no. 25, year LXX, January 30, 2020.

16. Simin- Jovićević, M., Živkucin S. (2020), Implementation of intellectual property in the sector of small and medium enterprises (SMEs) in Vojvodina, Monograph, Provincial Secretariat for Higher Education and Scientific Research, Novi Sad, ISBN 978-86-900221-4-4, p. 1-156 [In Serbian: Симин- Јовићевић, M., Живкуцин С. (2020), Примена интелектуалне својин у сектору малих средњих предузећа (МСП) у Војводини, Монографија]

17. Simin-Jovićević, M., Jovićević. P., Novaković S. (2016), Appellation of Geographical Origin as a Generator of National Competitiveness, Economic of Agriculture Vol. LXIII,No.2, Beograd,569-585

18. Simin Jovićević M., (2012), Intellectual property and small and medium enterprises, Monograph, Andrejević Endowment, Belgrade, p. 1-98 [In Serbian: Симин Јовићевић М., (2012), Интелектуална својина и мала и средња предузећа, Монографија]

19. Simin Jovićević M., (2011), Implementation policy of intellectual property rights as a means for the development of small and medium enterprises in Serbia (18832008), PhD thesis, Faculty of Political Science, Belgrade. [In Serbian: Симин Јовићевић М., (2011),Политика примене права интелектуалне својине као средство за развој малих и средњих предузећа у Србији (1883-2008)] 
20. Stanković V., (2020) Results of agriculture and food industry of Serbia in foreign trade in 2019, Voice - Vojvodina Research and Analytical Center, Novi Sad [In Serbian: Станковић В., (2020) Резултати пољопривреде и прехрамбене индустрије Србије у спољнотрговинској размени 2019 године]

21. Tradenark Law (“Official Gazette RS”, no.6/2020) [In Serbian: Закон о жиговима, Сл.Гласник РС, бр.6/2020]

22. World Intellectual Property Indicators (2020), World Intellectual Property Organization (WIPO), Geneve. 